IJLRES - International Journal on Language, Research and Education Studies

ISSN: 2580-6777 (p); 2580-6785 (e)

DOI: $10.30575 / 2017-2018010412$

Vol. 2, No. 1, 2018

Page: 149 - 161

\title{
LEGAL THOUGHTS IN MEASRURING THE STRENGHT OF QIYAS AS FIKIH ZAKAT METHODOLOGY IN INDONESIA
}

\author{
Nispul Khoiri \\ School of Postgraduate, State Islamic University of North Sumatra, Indonesia \\ nispul72@gmail.com
}

\begin{abstract}
This study aims to know the legal thoughts in measuring the strength of qiyas as the methodology of Jurisprudence of zakat in Indonesia. This research is a qualitative research based on the literature. The results of this study indicate the existence of the fact that the minds that developed visible: First, to support that qiyas is the legal argument including to adopt about the law of prison in Indonesia, this opinion raised by Jumhur ulama especially Imam Syafii who has provided enough space to the existence of qiyas. Secondly, the thought of rejecting qiyas as an argument of Islamic law, this opinion was expressed by the Mu'tazilites, the Zahiriyya and the Imami Shi'ah rejected the use of qiyas absolutely. Thirdly, the group that does not place qiyas as a proposition but qiyas is placed as a method of ijtihad, this opinion put forward by Imam alGhazali, Abu Zahrah and Ahmad Hasan. Fourth, the Group of contemporary minds especially developed in Indonesia, such as Hasbi Ash-Shiddieqy and others that qiyas within the boundaries of al-Syafi'i cannot meet the needs because the search process illat so complicated and rigid. Fifth, keterbatasn qiyas in adopting the law of prison in Indonesia lies only to see illat that is naqliyah (nash) means illat which is based on the provisions of texts.
\end{abstract}

Keywords: Legal Thought, Qiyas, the Fikih Zakat Methodology in Indonesia.

\section{INTRODUCTION}

The law of zakat in Indonesia in its development has raised many new legal issues. In the beginning zalcat is categorized as an aspect of the law of worship, but its development is in contact with Muammalat and Islamic economics and requires a law that must be clear and decisive. Fatwas - the fatwa of zakat by MUI has not responded much to the needs of jurisprudence of zakat in Indonesia, whereas the potential of zakat resources is so developed. Reinterpretation asnaf zakat is a legal requirement that must be responded and anticipated. Viewed from the potential sources of zakat in Indonesia, especially from the sectors of modern economy is an important object that continues to grow and must be considered.

The space for a review of the laws relating to contemporary zakat is quite open, with the criteria used also quite clear: (1). The source of zakat is still considered a new thing, so have not get the discussion in depth, especially in the books of classical 
Jurisprudence. (2). these zakat sources are the main feature of modern economy, so that every developed and developing country is a potential source of zakat. Such as zakat property investment, zakah on currency and other currencies. (3). Source of zakat related to legal entity. During this time zakat is always associated with obligations that are individual, so that the legal entity that berproduktifitas not categorized as the source of zakat. Therefore, zakat must be viewed from the point of muzakki at once with his wealth. (4). Sources of zakat modern sector has a high economic value that continues to grow and need to receive attention and decisions of zakat status, such as the cultivation of orchid plants, seaweed, ornamental fish and other. ${ }^{1}$

The opening of space to accommodate the new laws of zakat in Indonesia should begin with the placing of the clear fiqh ushul, as indeed, as al-Muqhits says, ushul fiqh is the methodology of Islamic law itself, and the product is fiqh. Where there is jurisprudence, then there is ushul jurisprudence that always accompanies its presence. Both can not stand on their own, but always run like two sides of inseparable coins. Therefore, the understanding of Islamic law should be put in an integrative sense between the jurisprudence and its usuls and not the jurisprudence alone. ${ }^{2}$

The power of qiyas becomes the unit of analysis in this study so it is known to what extent the power of qiyas in responding, establishing and discovering the emerging legal laws. So this topic diaggap important to be developed in this research.

\section{LITERATURE REVIEW}

No cases appear apart from the law, and we believe that every case or event that happens there is always the law. Some of the laws can be seen clearly in the syara 'syash' and others are not clear. Among the unclear laws have in common the nature of the case with a clear legal, with the concept of "muamatsalah". Events that are not clearly legal can be likened to the law with existing laws in the texts. Although it clearly does not use nash, but because it is equated with the existing law nashnya, then the way of determination like this can be said to use sharia 'texts indirectly or called qiyas (analogy). ${ }^{3}$

\footnotetext{
${ }^{1}$ Ibid., h. 91-92

${ }^{2}$ Abdul Mughits, Kritik Nalar Fikih Pesantren, (Jakarta : Kencana, 2008) h. 24

${ }^{3}$ Muhammad Hasbi Ash-Shiddieqy, Ushul Fikih, h. 170 - 171
} 


\section{Legal Thoughts In Measruring The Strenght Of Qiyas As Fikih Zakat Methodology In Indonesia}

DOI: 10.30575/2017/IJLRES-2018010412

The above thought becomes the basic principle of opening the use of qiyas as legal proposition. That is, the role of qiyas can play a broad role in adopting every law that emerges. Illat as one of the pillars of qiyas plays an important role in the development of qiyas. Illat as understood by Abu Hasan Muhammad al-Bishri is the reason / motive which in itself affects the existence of law. Imam al-Ghazali also gives understanding; Illat is a motive that affects the existence of the law with the cause set by God. The function of Illat ensures by itself the existence of the law both in the ordinance of God and by itself. With this function among scholars Syafii that illat al-muarrif li alhukm and illat can reach other legal cases. ${ }^{4}$

There are differences of opinion among scholars in looking at illat and wisdom. According to al-Shatibi illat and wisdom are two things intact, illat is the wisdom itself in the form of maslahat or mafsadat associated with the stipulation of the command, the prohibition or the permissibility of both are clear or not, mudhabit or not. Thus illat it is maslahat and mafsadat itself, so the law is determined by wisdom not based on illat. Wisdom is zahir but not mundhabit. The wisdom will become illat after being declared mundhabit. So here is sought mazhinnat it, the indicator that explains that wisdom can be declared mundhabit. For example shalat qasar. Establish whether or not the shalat qasar, illat it is safar or traveling. While masyaqqat or difficulty is wisdom permissible prayer. So whether or not to perform qasar according to their prayers depends on the presence or absence of illat, ie travel is considered as an indicator (mazhinnad) the existence of masyaqqat. Another example of syuf'a, namely the right of purchase for a union with a seller in a plot of land or residence. The fellowship is an illusion of the right of syufah. While the wisdom is to avoid difficulties arising from the entry of others who are not allies. The fellowship is made illuminated by the right of syufah, because it is assumed to be the entry of other elements in the fellowship, it will be this difficulty which is regarded as mazhinnat. In the field of worship illat is merely a benefit, there is no influence on the law istinbath, illat is not effective, because qiyas in the field of worship can not be applied. While in the muamalath aspect, illat is effective in

\footnotetext{
${ }^{4}$ Sulaeman Abdullah, Dinamika Qiyas Dalam Pembahasan Hukum Islam (Jakarta : Pedoman Ilmu Jaya, 1996) h. 136
} 
establishing the law. It is based on the theory that the muamalat aspect can be known to the wisdom and the secret (ma'qulat al-makna) while the aspect of worship is not. ${ }^{5}$

According to Wahbah al-Zuhaili, Illat and wisdom are two different things. Illat is a certain character that can be known objectively (zahir) and has a benchmark (mundhabith) in accordance with the provisions of law (munasib) whose existence is the determinant of the existence of law. While wisdom is something that becomes the purpose or purpose disyariatkannya law in the form kemaslahatan for humans. Actually as written by Fathurrahman Djamil, the difference between the two lies in the role in determining the existence or absence of illat law which is a close goal and can be used as the basis for the determination of the law, while the wisdom is a distant goal and can not be used as the basis for the determination of the law. In other words illat is a known trait and becomes the birth factor of a law or not. While wisdom is the ultimate goal of sharia.

However, the limitations of illat have always been a concern, because it is not always illat able to place itself in every law that arises. Cases and events of law can not always be found illat with the law of origin. It is here that illat has its limitations. When illat is limited the qiyas function will not be able to reach all the legal issues. This is where the role of ijtihad is required as a legal theory that constantly mendinamiskan laws that appear. Therefore the methods of developing ijtihad such as Istihsan, Maslahah alMusrsalah, Urf, Sadd al-Zara'i, Maqasid al-Shariah and others are needed in responding to legal needs including the issue of zakat in Indonesia.

\section{METHODOLOGY}

This is a type of library research. Library research is a process of collecting sources of literature, whether in the form of books, encyclopedias, journals, magazines, and others. The method used in this research is a qualitative method that emphasizes more on process aspect than just result. Qualitative research has a natural field as a direct and naturalistic source of data. So the approach used in this research is philosophical and historical method. Philosophical approach is used in order to occupy the essence of social change, whether as a legal theory or method, both in a formal and normative jurisdiction. While the historical approach is used in order to track the historical data of thoughts that talk about social change both in Indonesia, and from outside Indonesia.

\footnotetext{
${ }^{5}$ Ibid. Lihat, Nispul Khoiri, Usul Fikih (
} 


\section{Legal Thoughts In Measruring The Strenght Of Qiyas As Fikih Zakat Methodology In Indonesia}

DOI: 10.30575/2017/IJLRES-2018010412

This research is descriptive. It is considered appropriate to describe something, usually in this study, researchers have got / have a picture of the initial data about the problems to be studied. Aspects of the description elaborate historical literature data. Then a descriptive field phenomenon was analyzed with the literary data source and literary framework with a philosophical and historical approach..

\section{FINDINGS AND DISCUSSION}

\section{Relationship Qiyas with the Development of Fikih Zakat in Indonesia}

Fikih of zakat in Indonesia has experienced a fairly rapid dynamics. Zakat is not only oriented to worship alone, but has manifested itself to be part of the Islamic economy. Along with the speed of growth and economic development of the community, the state displays various sectors of property types that can be used as a potential source of zakat in this country. Starting from the agricultural sector, trade, livestock as well as new types of property from the modern sectors, such as industry, services and others. Even more dominant role, so it can bear various businesses and services of high economic value. It is supposed to be the sectors of wealth that developed in this modern economy serve as an important object in the discussion of zakat through the methods used.

In addition, zakat management aspects are also considered. If previously the management of zakat is traditional, modern needs currently require zakat must be managed professionally and modern. Good management will have implications for the increased amount of zakat collection itself. Moreover the potential of zakat in Indonesia is quite large and demands serious digging. It will not be touched maximally if it is not done in good management. The management process and all aspects related to it must also be based on the law as their proposition and legal basis.

The issue that is not less important is the need for legal development especially related to the asnaf-asnaf zakat and its indicators. The existing zakat asnafs require reinterpretation in order to provide the substance of the nash messages themselves. For example asnaf indigent, the standard of the classical cleric's interpretation will be different from today's context. Similarly asnaf riqab (servant) requires reinterpretation because the servant intended by classical interpretation is also different from the context 
of today. It could even be that the slaves in question are no longer found today or may be able to develop with various humanitarian cases today that need to be considered.

The above problems require the establishment of new laws and discovery. When it is not found in the nas (Qur'an-hadith) then the space of ijtihad is increasingly important. Ijtihad is the source of dynamics against the Qur'an and hadith. The role of ijtihad shows that all contemporary legal cases can be adopted with the role of ijtihad together with the methods of developing ijtihad itself. Moreover, the Qur'an when talking about zakat using two methods, namely the method of tafsāli and the method of ijmāl. ${ }^{6}$ The method of tafsiliah describes various assets that have fulfilled the obligatory obligatory obligation. Surely this source of zakat has been determined by the nas based on the types of treasures that developed at that time. ${ }^{7}$ The method of ijmāl is that all sorts of possessions meet the requirements of zakat which can be used as a source of zakat. Sources of zakat like this certainly not found in the time of the Prophet, but at this time developed and economic value, it can be used as a source of zakat. ${ }^{8}$

Qiyas as part of the method of developing ijtihad is definitely required by the law of zakat in Indonesia. Because qiyas serves as one of the propositions of the development of jurisprudence of zakat. Many of the issues of zakat that have been found by law through qiyas. For example, when laying the mandatory zakat rice law as the main source of Indonesian society that has been explained by the texts, then examined the nash as qiyas back. It turns out that in the texts, the Prophet has mentioned that wheat is one of the four basic types of obligatory zakat (From Abu Musa al-Asari and Muaz that the Prophet has said to both of them, do not you take zakat (from the inhabitants) except for four types: : Syair (a kind of wheat), wheat seeds, grapes and dates.). ${ }^{9}$ Dari uraian di atas menunjukkan dalam qiyas gandum sebagai pokok, padi sebagai cabang, wajib zakat atas gandum adalah hukum. Ketika dihubungkan padi dan gandum ditemukan illat yakni sama sebagai makanan pokok. Maka padi diwajibkan zakat sebagaimana halnya dengan gandum.

\footnotetext{
${ }^{6}$ Didin Hafidhuddin, Zakat Dalam Perekonomian Modern (Jakarta : Gema Insani, 2002) h. 91.

${ }^{7}$ Nispul Khoiri, Hukum Zakat di Indonesia (Bandung : Cita Pustaka Media Perintis, 2012) h. 2137.

${ }^{8}$ Didin Hafidhuddin, Zakat Dalam Perekonomian Modern, h. 91

${ }^{9}$ Al-San'ani, Subulus Salam (Bandung : Maktabah Dahlan Mutazam al-Tab'I wal al Nasyr, tt)
} Jilid. 2. h. 132 


\section{Legal Thoughts In Measruring The Strenght Of Qiyas As Fikih Zakat Methodology In Indonesia}

DOI: 10.30575/2017/IJLRES-2018010412

From the above explanation, it is clear that there is still room for ijtihad to adopt the laws of zakat in Indonesia. This is correlated with when the Koran through the ijmal approach has outlined the renewal of zakat fiqh through the general arguments of the verses, because with the growth of the people's economy, the emergence of various sectors of society's diverse and high economic value must be accommodated with legal certainty which is clearly a potential source of zakat. Moreover, this discourse is associated with social issues, then until whenever zakat is a matter that always remain actual, interesting to be discussed, because he was in touch with the socio-economic community and even the state. In its contents, it is definitely zakat and the matter will become a law that continues to move needed by the people of Indonesia.

\section{Legal Thoughts for Measuring the Power of Qiyas as the Fikih of Zakat Methodology in Indonesia}

Qiyas become part of the legal needs including the jurisprudence of zakat in Indonesia. The capacity of qiyas as a legal methodology has significance in the dynamics of society and the development of the law itself. In the context of zakat law, prosecuted and qiyas to answer the legal issues that arise. However, the question is whether the ability of qiyas can provide a broad role or not. If holding on to an opinion that receives qiyas as a legal proposition in addition to nash support and assumes the existence of a limited texts, while new problems with no arguments appear. then, ijtihad by using qiyas is mandatory. ${ }^{10}$

Not a few of the scholars / jurists who fear the limitations of qiyas itself to adopt legal issues including the law of zakat in Indonesia. Some analysis and opinions are mapped below:

a. The classical clerical groups of the Mu'tazilites, the Zahiriyads and the Imami Shi'a rejected the use of qiyas absolutely. These scholars argue: First, Qs alBaqarah: 29 which shows that sharia or Islam is perfect and does not require qiyas because nash comes to explain everything with clear and clear both related to obligatory, haram, makruh, circumcision and mubah. Second, to question the existence of zhanni illat in determining the law. Because qiyas not to bring to the level of confidence. Third, they cling to friends like Abu Bakr and Ibn Mas'ud

\footnotetext{
${ }^{10}$ Zakariya al-Bisri, Masadir al-Ahkam al-Islamiyah (Kairo Dar al-Ittihad, 1975) h. 98 - 99. Bandingkan Romli Muqaranah Mazahib fi Ushul (Jakarta : Gaya Media Pratama, 1999) h. 134
} 
deny qiyas and remind him to be cautious of ra'yu. Likewise Umar Ibn Khattab is also mindful of ra'yu. ${ }^{11}$

b. Groups that do not place qiyas as propositions but qiyas are placed as ijtihad methods. This opinion was put forward by Imam al-Ghazali, Abu Zahrah and Ahmad Hasan. According to al-Ghazali qiyas is a way of generating the law of nash reasoning through analogy. In other words al-Ghazali says that qiyas is not a legal proposition. Even in the book al-Mustasfa al-Ghazali did not include qiyas in orderly postulates as seen among the majority of scholars of the school. According to al-Ghazali which includes the rule of law are: the Qur'an, sunnah, ijma ', al-Istishab, Qaul Sahabi al-Istihsan and al-Istislah. The last is mentioned as a reasonable argument. ${ }^{12}$

c. Groups of contemporary minds, especially the developing minds in Indonesia that question the existence of qiyas and their scope. According to Hasbi AshShiddieqy, ${ }^{13}$ that qiyas within the boundaries of al-Shafii can not meet the needs because the search process is so complex and rigid illat. Hasbi Ash-Shiddieqy added that in fact besides the Islamic legal thought formulated in the jurisprudence books, some of them are the fiqh of Hijazi, the fiqh that is formed from the customs of the Hijaz, or the jurisprudence of Mishri, the jurisprudence that accommodates Egyptian customs, or fiqh Hindi jurisprudence formed on the urf of India. During this time we have not shown the ability to berijtihad to realize the jurisprudence in accordance with the characteristics of Indonesia, sometimes we impose fiqh Hijaz, Egyptian jurisprudence and Islamic jurisprudence applied in Indonesia on the basis of taqlid. ${ }^{14}$ According to Imam Syaukani, the jurisprudence that developed in Indonesia is dominantly colored by Arabic character (Arab oriented) and more closely attached to the tradition of the Syafii school. This reality is seen from the literature used by scholars of most of the books of Jurisprudence Syafii as an example of Compilation of Islamic Law

\footnotetext{
${ }^{11}$ Ibid.

${ }^{12}$ Ibid. Lihat al-Ghazali, al-Mustasfa (Mesir : Maktabah al-Jundiyah, 1971) h. 394.

${ }^{13}$ Muhammad Hasbi Ash-Shiddieqy, Syariat Islam Menjawab Tantangan Zaman (Jakarta : Bulan Bintang, 1966) h. 41-42

${ }^{14}$ Ibid., Lihat, Imam Syaukani, Rekonstruksi Epistemologi Hukum Islam Indonesia dan Relevansinya Bagi Pembangunan Hukum Nasional, h. 92-93
} 


\section{Legal Thoughts In Measruring The Strenght Of Qiyas As Fikih Zakat Methodology In Indonesia}

DOI: 10.30575/2017/IJLRES-2018010412

literature (Inpres No. 1/1991) as a legal reference in the Religious Courts. ${ }^{15}$ Besides being patterned on the books of fiqh syafii, in the methodology aspect mostly stuck in the books of ushul fiqh in Shafii's school which mostly focused on the discussion of qiyas, (other than the Qur'an, hadith and ijma '). In other words the discussion of ijtihad is only framed in qiyas, according to Imam Syafii ijtihad is qiyas itself. In his opinion many critics, one of them by his own followers al-Ghazali said: "Whoever says qiyas and ijtihad two pronunciations, then he has made a mistake" (Man qala anna al-qiyas wa al-ijtihad lafdzani faqad khata '). 16

Based on the above explanations, it indicates the occurrence of difference of opinion as well as the contradiction of legal thoughts that there are limitations of qiyas in adopting legal issues including the law of Indonesian law. Although the above opinion is not directly focused on the issue of perzakatan, but the dynamics of law of law in Indonesia as part of the contemporary law, then include the legal dynamics that is adopted by qiyas.

In the context of Indonesian research, research on finding common ground between principal and branch will be a separate legal issue for the future. That is not always the law of prison starting from the determination of sources, reinterpretasi mustahik zakat, zakat management can be equated its nature between principal and branch. Perhaps in the zakat source potential is still open to be equated, because the potential sources of zalcat-sanggur growing can still be analogous to wheat, wheat, grapes and other grains. But in the aspect of management, the development of asnaf zakat and others will be hampered to the limitations of illat itself, unless illat dirobah not seen based on provisions that have been established sharia.

\footnotetext{
${ }^{15}$ Terdapat 38 kitab menjadi literatur KHI sebagian besar bermazhab Syafii yaitu : al-Bajuri, Fath al-Muin, Syarqawi 'ala al-Tahrir, Mughni al-Muhtaj, Nihayah al-Muhtaj, al-Syarqawi, I'anat al-Thalibin, Tuhfah, Tarqi al-Musytaq, Bulghah al-Salik, Syamsuri fi al-Fara'id, al-Mudawanah, Qalyubi/Mahalli, Fath al-Wahhab dan Syara, Bidayah al-Mujtahid, al-Umm, Buughyah al-Mustar-syidin, al-'Aqidah wa alSyariah, al-Muhalla, al-Wajiz, Fath al-Qadir, al-Fikih 'ala al-Mazahib al-Arbaah, Fikih al-Sunnah, Kasyf al-Ghina, Majmu'at al-Fatawa al-Kubra li Ibn Taymiyyah, Qawanin al-Syariah li al-Sayyid 'Utsman Ibn Yahya, al-Muqhni, al-Hidayah Syarh al-Bidayah, Qawanin al-Syariah li al-Sayyid Sadaqah Dahlan, Nawab al-Jalil, Syarah Ibn Abidin, al-Muwaththa, Hasyiyah al-Dasuki, Badai' al-Sanai', Tabyin alHaqa'iq, al-Fatawa al-Hindiyah, Fath al-Qadir dan al-Nihayah. Imam Syaukani, Rekonstruksi Epistemologi Hukum Islam Indonesia dan Relevansinya Bagi Pembangunan Hukum Nasional (Jakarta Raja Grafindo Persada, 2006) h. 90-91

16 Ibid.
} 
If the above theory, used as an indicator measure the strength of qiyas, then when determining illat perzakatan in Indonesia, it will be found difficulty and true that illat will be limited. Because not all cases of juridical law in Indonesia can be adopted by the texts, let alone the stipulation of the provisions of the similarity of basic properties with the nature of the branch. Certainly qiyas process using the same illat will be different. However, if used illat through the process of ijtihad open possibilities materialized research on the similarity between the branch and the illat. Because the process is done through ijtihad. It takes sharpness of mind to dismantle and determine what is the reason for a syara law '. Because nash does not mention or do not give a hint about the reasons behind the legal provisions.

\section{CONCLUSION}

From the above explanation can be drawn important conclusions related legal thoughts that develop in measuring the strength of qiyas as methodology of Jurisprudence of zakat in Indonesia is very diverse with the proposition and different approaches :

1. The existence of the mind supports that qiyas is a legal argument including can adopt about the law of prison in Indonesia. This opinion is expressed by the jumhur ulama especially Imam Syafii which has given enough space to the existence of qiyas. According to the opinion in this group, there is no limitation of qiyas. If qiyas is not found in the texts then qiyas can be done through the process of ijtihad.

2. The mind rejects qiyas as a proposition of Islamic law. This opinion was found by the Mu'tazilites, the Zahiriyads and the Imami Shi'ah refused the absolute use of qiyas. These scholars argue Qs al-Baqarah: 29 which shows that sharia or Islamic religion has smpurna and does not require qiyas because nash comes to explain everything with a clear and clear both related to obligatory, haram, makruh, circumcision and mubah. Questioning the existence of zhanni illat in determining the law. Because qiyas not to bring to the level of confidence. They cling to the friends deny qiyas and remind them to be cautious of ra'yu.

3. The group does not place qiyas as a proposition, but qiyas is placed as a method of ijtihad. This opinion was put forward by Imam al-Ghazali, Abu Zahrah and Ahmad Hasan. According to al-Ghazali qiyas is a way of generating the law of 
nash reasoning through analogy. In other words al-Ghazali says that qiyas is not a legal proposition. Even in the book al-Mustasfa al-Ghazali did not include qiyas in orderly postulates as seen among the majority of scholars of the school. According to al-Ghazali which includes the rule of law are: the Qur'an, sunnah, ijma ', al-Istishab, Qaul Sahabi al-Istihsan and al-Istislah.

4. Groups of contemporary minds, especially the developing minds in Indonesia, such as Hasbi Ash-Shiddieqy, Abdul Muqhit and others. According to Hasbi Ash-Shiddieqy, that qiyas within the boundaries of al-Syafii can not meet the needs because the search process is so complicated and rigid. Hasbi AshShiddieqy added that in fact besides the Islamic legal thought formulated in the jurisprudence books, some of them are the fiqh of Hijazi, the fiqh that is formed from the customs of the Hijaz, or the jurisprudence of Mishri, the jurisprudence that accommodates Egyptian customs, or fiqh Hindi jurisprudence formed on the urf of India. According to him it is time we show the ability to berijtihad to realize the jurisprudence in accordance with the characteristics of Indonesia.

5. Limitations qiyas in adopting the law of prison in Indonesia lies only to see illat that is naqliyah (nash) means illat based on the provisions of the texts. That is not always illat naqliyah can be equated with cases of contemporary legal perzakatan in Indonesia. However, if illat is based on illat through ijtihad process, it is examined based on the similarity of principal and branch outside of Shari'a regulation it is quite open. Although complicated and forced sharpness of thinking, then the space to do qiyas quite open and there are no limitations

\section{BIBILIOGRAPHY}

Abdu al-Wahab Khallaf, Mashadir al-Tasyrik al-Islami fima la nashsha (Kuwait : Dar al-Qalam, 1972)

Abdul Karim Zaidan, al-Wajiz Fi Ushul Fikih (Baqhdad : Dar al-Arabiyah Liitiba'ah, 1977)

Abdul Mughits, Kritik Nalar Fikih Pesantren, (Jakarta : Kencana, 2008)

Abu Hamid Muhammad Ibn Muhammad al-Ghazali, Syifa al-Ghalil fi Bayan alSyubh al-Muhil wa Masalik al-Ta'lil (Mesir: Maktabah al-Azhar, t.t) 
Abu Hasan Muhammad al-Bishri, al-Muktamad Fi Ushul al-Fikih (Beirut : Dar alKutub al-Ilmiyah, 1983) Jilid II

Abu Hasan Thalib, Tatbiq al-Syariah al-Islamiyah fi al-Bilad al-Arabiyah (Kairo : Dar al-Nahdah al-Arabiyah, 1990) Cet. III

Al-Amidi, Ali Ibn Abi Ali Ibn Muhammad, al-Ahkam fi Usul al-Ahkam (Mesir : Dar al-Fikr, 1928)

al-Ghazali, al-Mustasfa (Mesir : Maktabah al-Jundiyah, 1971)

Al-San'ani, Subulus Salam (Bandung : Maktabah Dahlan Mutazam al-Tab'I wal

al Nasyr, tt) Jilid. Zakariya al-Bisri, Masadir al-Ahkam al-Islamiyah (Kairo Dar al-

Ittihad, 1975)

Al-Syatibi, al-Muwafaqat, Jilid. 1 h. 185. Lihat, Fathurrahman Djamil, Metode Ijtihad Majlis Tarjih Muhammadiyah (Jakarta : Logos Publishing Hause, 1995)

Bambang Waluyo, Penelitian Hukum Dalam Praktek (Jakarta : Sinar Grafika, 1996)

Didin Hafidhuddin, Zakat Dalam Prekonomian Modern (Jakarta : Gema Insani Pres, 2002)

Imam Syafii, al-Risalah (Mesir : Dar al-Saqafah, 1969)

Imam Syaukani, Rekonstruksi Epistemologi Hukum Islam Indonesia dan Relevansinya Bagi Pembangunan Hukum Nasional (Jakarta Raja Grafindo Persada, 2006)

Lahmuddin Nasution, Pembaharuan Hukum Islam Dalam Mazhab Syafii

(Bandung : Remaja Rodakarya, 194)

Mahsun Fuad, Hukum Islam Indonesia Dari Nalar Partisipatoris Hingga Emansipatoris (Yogyakarta, LKIS, 2005)

Muhammad Abdul Gani Baqiyani, al-Madkhal Ila Ushul al-Fikq al-Maliki (Beirut Libanon : Dar Ribnan Littiba'i wa al-Nasyr, 1968)

Muhammad Ali al-Syais, Nasyah al-Figh al-Ijtihad wa atwaruh (Kairo : Majma alBukus al-Islamiyah, 1970)

Muhammad Hasbi Ash-Shiddieqy, Syariat Islam Menjawab Tantangan Zaman (Jakarta : Bulan Bintang, 1966)

Muhammad Hasbi Ash-Shiddieqy, Ushul Fikih (Jakarta, Kencana, 2009) Jilid 1. Cet. III

Nispul Khoiri, Hukum Zakat di Indonesia (Bandung : Cita Pustaka Media Perintis, 2012)

Romli, Muqaranah Mazahib fi Ushul (Jakarta : Gaya Media Pratama, 1999) 
Legal Thoughts In Measruring The Strenght Of Qiyas As Fikih Zakat Methodology In Indonesia

DOI: $10.30575 / 2017 /$ IJLRES-2018010412

Satria Efendi, Ushul Fikih (Jakarta : Kencana, 2005)

Suleman Abdullah, Dinamika Qiyas Dalam Pembaharuan Hukum Islam Kajian Qiyas Imam Syafii (Jakarta: Pedoman Ilmu Jaya, 1996)

Sya'ban Muhammad Ismail, al-Tasyr' al-Islami Masadiruh wa at-Wuruh (Kairo : Maktabah Nahdhah al-Misriyah, 1985) Cet II 